potrafił współpracować z ludźmi o różnych światopoglądach (m.in. z Matką Różą Czacką - założycielką Zgromadzenia Sióstr Franciszkanek Służebnic Krzyża i Zakładu w Laskach, Michałem Wawrzynowskim - wybitnym metodykiem edukacji specjalnej, Heleną Radlińską - twórczynią polskiej pedagogiki społecznej czy Januszem Korczakiem). Wśród uczestników spotkania rozprowadzono wydane w formie książkowej materiały konferencyjne (zawierające, poza wymienionymi, także referat dr Edyty Głowackiej-Sobiech z UAM w Poznaniu, zatytułowany „Maria Grzegorzewska i Olga Małkowska - żywoty równoległe”) oraz foldery prezentujące pacę Zespół Szkół Specjalnych im. Marii Grzegorzewskiej w Żarach.

Tomasz Fetzki

\title{
Konferencja pt. „Całożyciowe uczenie się jako wyzwanie dla teorii i praktyki edukacyjnej" (Gniezno, 21-22 czerwca 2010)
}

W drugiej połowie czerwca 2010 roku w Kolegium Europejskim im. Jana Pawła II w Gnieźnie odbyła się interesująca ogólnopolska debata, której głównymi celami stały się z jednej strony refleksja teoretyczna nad różnymi obszarami kształcenia ustawicznego i edukacji dorosłych, z drugiej zaś - wymiana doświadczeń na temat badań oraz prezentacja tzw. dobrych praktyk w tym zakresie. Konferencję zorganizował Zakład Kształcenia Ustawicznego i Doradztwa Zawodowego Uniwersytetu Adama Mickiewicza w Poznaniu. Kierownictwo naukowe i organizacyjne całości sprawowała prof. dr hab. Ewa Solarczyk-Ambrozik, sekretarzem konferencji była zaś dr Małgorzata Rosalska.

Jak wskazywali organizatorzy w przedkonferencyjnych komunikatach, ich zamiarem stało się stworzenie warunków do zaprezentowania podstawowych kierunków namysłu nad teoria i praktyka edukacyjna podejmowanych $w$ różnych ośrodkach akademickich i instytucjach praktyki edukacyjnej na terenie Polski ${ }^{1}$. Do udziału w przedsięwzięciu zaproszono zatem zarówno teoretyków - reprezentantów najważniejszych środowisk akademickich w kraju, w których podejmowana jest szeroko rozumiana problematyka andragogiczna, jak i praktyków - przedstawicieli placówek oświatowych, pracodawców, samorządów lokalnych, organizacji pozarządowych i innych środowisk, zaangażowanych w rozwój idei uczenia się przez całe życie.

Uczestnikom gnieźnieńskiego spotkania zaproponowano ponad dziesięć obszarów tematycznych. Oto one: (1) kierunki rozwoju refleksji i strategii badawczych w edukacji dorosłych; (2) polityka oświatowa - trendy, strategie, rozwiązania; (3) instytucjonalne

\footnotetext{
1 I Komunikat konferencyjny, Poznań, 23-01-2010
} 
konteksty kształcenia ustawicznego; (4) kształcenie ustawiczne na uniwersytetach i w szkołach wyższych; (5) adresaci usług edukacyjnych - ich potrzeby, uwarunkowania i charakterystyka; (6) biograficzność w edukacji dorosłych; (7) kształcenie ustawiczne a rynek pracy; (8) człowiek w miejscu pracy; (9) migracje zarobkowe i wielokulturowość w miejscu pracy; (10) nowe wyzwania i konteksty doradztwa zawodowego; (11) senior w przestrzeni edukacyjnej².

Wskazana problematyka wzbudziła znaczne zainteresowanie - głównie wśród polskich andragogów i „oświatowców”, którzy przybyli do gnieźnieńskiego Kolegium z terenu całego kraju bardzo licznie. W ciągu dwudniowej debaty zaprezentowano łącznie blisko pięćdziesiąt referatów i komunikatów z badań, poruszających różnorodne wątki $\mathrm{z}$ zasugerowanego przez komitet organizacyjny zakresu. W pierwszym dniu konferencji - odbyły się cztery sesje plenarne. Dzień drugi poświęcono na obrady w sekcjach oraz sesję końcową.

Konferencję otworzyły wystąpienia wstępne prof. dr hab. Ewy Solarczyk-Ambrozik - Przewodniczącej jej Komitetu Organizacyjnego, prof. dr. hab. Krzysztofa Krasowskiego - JM Rektora UAM oraz prof. dr. hab. Zbyszko Melosika - Dziekana Wydziału Studiów Edukacyjnych UAM, którzy zgodnie podkreślali ważność mającej za chwilę rozpocząć się debaty oraz wyrażali nadzieję, że gnieźnieńskie spotkanie przyniesie wymierne efekty zarówno od strony naukowej, jak i dla praktyki edukacji dorosłych w naszym kraju.

Następnie przystąpiono do realizacji programu pierwszej części obrad plenarnych. Złożyło się nań pięć referatów, a całość moderowali prof. dr hab. Kazimierz Przyszczypkowski (UAM) oraz prof. dr hab. Ewa Kurantowicz (DSW). Sesję rozpoczęło wystąpienie prof. dr hab. Ewy Solarczyk-Ambrozik nt. „Uczenie się przez całe życie jako rzeczywistość edukacyjna", w którym Autorka zawarła interesujące rozważania porządkujące możliwe sposoby naukowego (i popularnego) rozumienia zjawisk społeczno-kulturowych w obrębie edukacji dorosłych/kształcenia ustawicznego/całożyciowego uczenia się. W Jej referacie mogliśmy odnaleźć także wątki historyczno-oświatowe - związane głównie ze zmianą rozumienia koncepcji LLL (life long learning) na przestrzeni kilku ostatnich dekad. Prof. dr hab. Mieczysław Malewski (DSW) w referacie pt. „O postawie teoretycznego finalizmu" podjął z kolei zagadnienie kulturowych źródeł teorii andragogicznych. Dla historyka wychowania szczególnie interesująco zabrzmiały uwagi prelegenta na temat zależności między teorią a praktyką edukacji dorosłych, a zwłaszcza ich konkluzja, iż praktycy - traktowani przez lata przez teoretyków (,zadufanych akademików”!) z nieukrywaną wyższością - z czasem się wyemancypowali i dzisiaj świetnie radza sobie z praktyka edukacyjna bez tych ostatnich. O edukacji dorosłych z perspektywy kultury pospiechu mówił trzeci z referentów - prof. dr hab. Józef Kargul (DSW), który wskazał na powszechne dziś traktowanie wiedzy jako towaru, co powoduje konieczność szybkiego uczenia się (,jedynie rzeczy użytecznych”) i ...zapominania (,wiedza błyskawicznie starzeje się").

Dwa ostatnie referaty pierwszej sesji plenarnej dotyczyły problematyki studiowania w szkole wyższej. Najpierw prof. dr hab. Tadeusz Aleksander (Uniwersytet Jagielloński) podjął temat „Studia podyplomowe elementem całożyciowej edukacji”, w którym oprócz

${ }^{2}$ Ibidem. 
ukazania specyfiki i funkcji współczesnych studiów podyplomowych nie unikał też odwołań do dziejów tej akademickiej formy edukacyjnej. Następnie zaś prof. dr hab. Zbyszko Melosik (UAM) zajął się w referacie nt. „Dyplom akademicki i społeczne rekonstrukcje sukcesu życiowego" konsekwencjami ,ścieżkowania w edukacji”, co historycznie doprowadziło do utrwalenia się $\mathrm{w}$ różnych społeczeństwach merytokratycznego podejścia do wykształcenia, w którym to dyplom decyduje o dobrej pracy.

Drugą część obrad plenarnych poprowadzili prof. dr hab. Ewa Skibińska (UW) i prof. dr hab. Mieczysław Malewski. Zaprezentowano w niej sześć kolejnych referatów. Prof. dr hab. Bożena Wojtasik (DSW) w wystąpieniu pt. „Całożyciowe poradnictwo kariery w całożyciowym uczeniu się" wskazywała m.in. na przemiany, jakie zaszły w podejściu do poradnictwa pomiędzy okresem przed rokiem 1989, kiedy to jego zadaniem było głównie podejmowanie decyzji zawodowych za jednostkę, a współczesnością, kiedy to stało się ono partnerską pomocą jednostce w zarządzaniu własną karierą na kolejnych etapach życia. Autorka podkreślała też, iż sytuacja poradnicza może być traktowana jako sytuacja edukacyjna - zarówno dla doradcy, jak i dla poradobiorcy. O randze edukacji dorosłych na świecie w kontekście VI Światowej Konferencji Edukacji Dorosłych UNESCO „Confintea VI”, która odbyła się u schyłku ubiegłego roku w Ameryce Południowej z udziałem ponad 1,1 tys. uczestników ze 144 krajów (Belém - Brazylia, 1-4 grudnia 2009 r.), mówił prof. dr hab. Henryk Bednarczyk (ITE-PIB - Radom). Referujący, który był jednym z trzech Polaków biorących udział w tym kongresie, przypomniał pokrótce historię światowych konferencji edukacji dorosłych - od „Confintea I” (Helsignør - Dania,1949) do czasów współczesnych, a także zwrócił zebranym uwagę na fakt, że współcześnie problemy oświatowe świata (np. 1 mld analfabetów, edukacja sanitarna) wydają się być jedynie w kilku punktach zgodne z tymi zagadnieniami, które bywają najbardziej widoczne w edukacji dorosłych w Europie i w Polsce. Na marginesie referatu prof. Bednarczyka dodajmy, że w dyskusji po jego wystąpieniu pojawiły się ciekawe wątki historyczno-oświatowe prof. Agnieszka Stopińska-Pająk (UŚ) oraz prof. Tadeusz Aleksander (UJ) przypomnieli bowiem szeroko zakrojone prace przygotowawcze i udział delegacji polskiej w pierwszej Wszechświatowej Konferencji Oświaty Dorosłych w Cambridge w 1929 r.

Następne wystąpienie miało charakter cząstkowego raportu z międzynarodowego projektu badawczego. Był to komunikat z trzyletnich prac nad wspomaganiem uczenia się dorosłych prowadzonych przez siedem europejskich uniwersytetów w ramach projektu RANLHE (ang.: Access and Retention: Experiences of Non-traditional Learners in Higher Education"), który zaprezentowała - w imieniu prof. Ewy Kurantowicz i własnym - dr Adrianna Nizińska (DSW). Kolejnym komunikatem z badań w tej sesji plenarnej było wystąpienie prof. dr hab. Elżbiety Dubas (UŁ) pt. „Biografia - w nurcie andragogicznej refleksji i badań”, w którym podzieliła się ona uwagami na temat realizowanego od $2007 \mathrm{r}$. projektu „Biografia i badanie biografii”. Szczególnie ciekawie dla zainteresowanych historycznymi aspektami edukacji pobrzmiewały w Jej wystąpieniu wątki dotyczące uczenia się z własnej biografii/doświadczenia oraz uczenia się z namysłu biograficznego.

Ciekawym głosem w debacie stał również referat dr hab. Hanny Solarczyk-Szwec (UMK) nt. „Polifonia czy kakofonia znaczeń edukacji ustawicznej”, w którym Autorka stosując spektakularne zaczerpnięcia terminologiczne z obszaru muzykologii próbowała 
nakreślić współczesną panoramę poszukiwań terminologicznych, metodologicznych i praktycznych w obrębie andragogiki i edukacji dorosłych. Ostatni referat plenarny w części drugiej wygłosiła prof. dr hab. Eugenia Potulicka (UAM). Nosił on tytuł: „Założenia teoretyczne neoliberalizmu a jego praktyka edukacyjna". Referentka stanowczo podkreślała fakt, że zrozumienie współczesnych zjawisk edukacyjnych nie jest możliwe bez analizy ideologii, polityki i praktyki neoliberalizmu. Dopiero taka analiza - obnażająca „sterowaną atrofię państwa socjalnego” oraz „nadanie [przez neoliberalizm] „wymianie rynkowej rangi etyki" - umożliwi nam na przykład skuteczne zdiagnozowanie charakteru reform oświatowych (,pod kątem interesów korporacjonizmu”), w tym tych dotyczących edukacji dorosłych, w których „wychowawcą ma być wolny rynek”.

Kolejne dwie sesje plenarne odbyły się już w godzinach popołudniowych. Trzecią z nich poprowadzili wspólnie prof. Józef Kargul i prof. Tadeusz Aleksander, czwartą zaś - prof. Henryk Bednarczyk i prof. Bożena Wojtasik.

Sesję trzecią rozpoczął prof. dr hab. Kazimierz Przyszczypkowski refleksjami o bardziej ogólnym charakterze - referatem nt. „Edukacyjnych implikacji granic pozna(wa) nia”, w którym podkreślał, iż poznawanie nigdy nie ma charakteru liniowego, a nasz „świat kończy się tam, gdzie kończy się nasza wiedza”.

Aż dwa referaty, które pojawiły się w tej części obrad plenarnych, dotyczyły zagadnień z zakresu historii wychowania - a dokładniej z dziejów edukacji dorosłych. Pierwszy z nich został wygłoszony przez prof. dr hab. Agnieszkę Stopińską-Pająk. Autorka zatytułowała swoje wystąpienie „Z tradycji instytucjonalnej edukacji ustawicznej”. Zajęła się w nim charakterystyką wybranych inicjatyw z zakresu edukacji dorosłych, mających swój początek w ostatnich dekadach XIX stulecia. Spośród szeregu ówczesnych instytucji bardziej szczegółowo omówiła trzy z nich, odzwierciedlające różne typy edukacji ustawicznej: „Poradnik dla samouków” pod red. A. Hefflicha i S. Michalskiego (Tom I: 1898, łącznie tomów: 54); Uniwersytet Latający (zał. 1885) oraz uczenie się poprzez aktywność w licznych formach edukacji prowadzonej przez stowarzyszenia. W referacie prof. Stopińskiej-Pająk został też po raz kolejny sformułowany apel o większą troskę polskiego środowiska andragogicznego o badanie historii rodzimej edukacji dorosłych oraz o nawiązywanie we współcześnie prowadzonych projektach badawczych do polskich tradycji oświatowych. Jak bowiem podkreślała Autorka: w większości polskich opracowań z zakresu edukacji dorostych niewiele uwagi zajmuje historia, tak więc w odniesieniu do polskiej tradycji w tym zakresie możemy użyć określenia »zbiorowa niepamięć» lub »historia zapomniana (co zreszta potwierdzić musi na podstawie kilkuletnich już obserwacji ze smutkiem i sam autor niniejszego omówienia). Nie chodzi przy tym jedynie o „spłacenie długu” przez współczesnych pionierom polskiej myśli andragogicznej, ale o nadanie współczesnym pracom zakorzenienia, odpowiedniej perspektywy historycznej, albowiem brak tychże - jak podkreślała za Z. Kwiecińskim Referentka - „pozbawia perspektyw myślowych".

Drugi z plenarnych referatów historyczno-oświatowych został przygotowany wspólnie przez prof. dr hab. Wiesława Jamrożka (UAM) i prof. dr hab. Krzysztofa Jakubiaka (UG). Nosił on tytuł: „Idee edukacji ustawicznej w zachodnioeuropejskiej i polskiej tradycji edukacyjnej” i w zamyśle samych Autorów miał stanowić „,wprowadzenie do dyskusji” 
nad historycznymi przemianami podejścia do oświaty dorosłych w Europie i na ziemiach polskich. Całość stanowiła bowiem interesujący historyczny przegląd sposobów myślenia o edukacji dorosłych od czasów starożytnych - poprzez odrodzenie, oświecenie, okres zaborów i cały wiek XX - do czasów współczesnych. Przywołano między innymi poglądy: Platona, Komeńskiego, Helvetiusa, Condorceta, a na gruncie polskim - Libelta, Korniłowicza, Radlińskiej, Urbańczyka, Wroczyńskiego, Wojciechowskiego oraz idee edukacyjne takich gremiów, jak: KEN, TUL im. Mickiewicza, UNESCO (raporty Faure'a i Delorsa) czy Komisja Europejska (Biała Księga). Przy czym - co oczywiste - wybór postaci i idei nie był przypadkowy, a miał za zadanie zaprezentowanie głównej linii rozwojowej koncepcji całożyciowego uczenia się na gruncie europejskim (i rodzimym) na przestrzeni dziejów. Sam referat w imieniu Autorów wygłosił prof. Wiesław Jamrożek. Dobrze się zatem stało, zwłaszcza w kontekście przedstawionych wyżej uwag prof. Agnieszki Stopińskiej-Pająk na temat niedoceniania przez środowisko andragogiczne wątków historyczno-oświatowych, iż taki retrospektywny (chciałoby się wręcz rzec „misyjny”) szkic został, w czasie tak ważnej dla całego polskiego środowiska andragogicznego debaty, zaprezentowany.

Sesję trzecią uzupełniły jeszcze dwa wystąpienia: dr hab. Agnieszki Cybal-Michalskiej (UAM) pt. „Idea homo explorens jako remedium na odnalezienie się młodego człowieka w społeczeństwie globalnej zmiany”, w którym Autorka podkreślała, że właśnie idea jednostki poszukującej pozwala interpretować ,uczenie się jako nadające światu i jednostce sens" oraz duetu prof. dr hab. Alicji Siemak-Tylikowskiej i mgr Katarzyny Lubryczyńskiej (obie UW), omawiających po raz kolejny, często w ostatnich latach poruszaną przez Autorki tematykę, działalność Uniwersytetu Otwartego Uniwersytetu Warszawskiego.

W czasie czwartej sesji przeprowadzonej pierwszego dnia obrad zebrani mieli szansę wysłuchać dodatkowo jeszcze czterech referentów³. Rozpoczęło ją wystąpienie prof. dr hab. Ewy Skibińskiej pt. „Andragogiczne kształcenie studentów - między rygoryzmem standardów a refleksyjną swobodą", będące ważnym głosem w sprawie charakteru i zakresu współczesnego kształcenia andragogicznego w polskich uczelniach wyższych. $\mathrm{Na}$ „alternatywność dróg do pracy i zawodu w poprzemysłowym społeczeństwie wiedzy” zwrócił uwagę z kolei w swoim referacie prof. dr hab. Zdzisław Wołk (UZ), wskazując na „niejednoznaczny w dniu dzisiejszym charakter pojęcia wybór zawodu” i konieczność przygotowania się na różnych etapach edukacji do wielokrotnej zmiany miejsca pracy. Z kolei prof. dr hab. Dzierżymir Jankowski (WSH-Leszno) przedstawił własne refleksje, poparte długoletnim doświadczeniem w badaniu problematyki samokształceniowej, nt. „Edukacja i autoedukacja. Konteksty i współzależność”. Tezą wyjściową referatu uczynił stwierdzenie, że „owocność edukacji i rozwoju danej osoby możliwa jest jedynie w sytuacji komplementarności edukacji i autoedukacji”. W jego wystąpieniu pojawiło się

\footnotetext{
${ }^{3}$ Ostatnią sesję plenarną poprzedzono zebraniem otwartym Zespołu Pedagogiki Dorosłych KNP PAN, podczas którego przewodniczący Zespołu - prof. dr hab. Tadeusz Aleksander oraz jego sekretarz - dr Krzysztof Pierścieniak (UW) przedstawili sprawozdanie z jego działalności za ostatnie lata.
} 
wiele odwołań do historii poglądów na samokształcenie na gruncie polskim - a w szczególności prac Spasowskiego, Znanieckiego, Okińskiego i Suchodolskiego.

Ostatni z referentów - prof. dr hab. Jerzy Stochmiałek (UKSW) w swojej wypowiedzi nt. „Znaczenie całożyciowego uczenia się w przezwyciężaniu wybranych kryzysów życiowych" zaakcentował konieczność uwzględnienia w praktyce edukacyjnej dorosłych zagadnień przygotowujących z jednej strony do przezwyciężania trudności życia codziennego, z drugiej zaś - do przezwyciężania sytuacji kryzysowych przez jednostkę.

Kończąc omówienie problematyki obrad pierwszego dnia konferencji podkreślmy jeszcze, że podczas wszystkich czterech części sesji plenarnych ich uczestnicy mieli czas na dyskusję, z czego wielu z nich skrzętnie skorzystało.

Drugi dzień konferencji rozpoczęły obrady w sekcjach. Dla porządku wymieńmy tytuły referatów, które pojawiły się w poszczególnych z nich oraz nazwiska i afiliacje ich Autorów.

W sekcji I - moderowanej przez dr hab. Hannę Solarczyk-Szwec i dr Monikę Bartkowiak (UAM) wystąpiło czworo referentów, którzy „,skupili się głównie na analizach różnych miejsc uczenia się"4. Uczestnicy sekcji wysłuchali, a następnie przeprowadzili dyskusję nad następującymi referatami: „Edukacja uniwersytecka w edukacji całożyciowej” dr Agnieszki Majewskiej-Kafarowskiej (UŚ), „Proces kształcenia na Uniwersytecie Harvarda, w Heidelbergu oraz w Tokio” dr Darii Hejwosz (UAM), „Miejsca uczenia się” dr Doroty Gierszewskiej (UJ) oraz „Gry w edukacji dorosłych - inspiracje badawcze” mgr. Wojciecha Świtalskiego (UŁ).

Sekcja II poprowadzona była przez prof. dr hab. Agnieszkę Stopińską-Pająk i dr Małgorzatę Rosalską. Jej ,problematyka dotyczyła edukacji w środowisku życia - lokalnym, regionalnym, miejscu zamieszkania...”. Złożyło się nań sześć wystąpień: „Uczenie się obywatelstwa przez dorosłych na terenach zagrożonych marginalizacją" dr Natalii Sokołowicz (AP-Słupsk), „Społeczny wymiar edukacji w środowiskach lokalnych” dr Anny Panek i dr Zofii Szaroty (obie UP im.KEN), „Idea wyższej szkoły ludowej w koncepcjach pracy oświatowej ks. Antoniego Ludwiczaka” dr. Tomasz Maliszewskiego (UG), „Idea regionalizmu w udoskonalaniu procesu edukacji permanentnej” dr Beaty Boczukowej (UP-Siedlce), „Kształcenie ustawiczne w planach rozwoju środowisk lokalnych (na przykładzie lokalnych strategii rozwoju)” dr Beaty Cyboran (UJ) oraz „W labiryncie symboli i znaczeń. O społecznym uczeniu się w środowisku pracy" mgr Magdaleny Czubak-Koch (DSW).

Obrady sekcji III „koncentrowały się wokół problematyki edukacji ustawicznej”, a kierowali nią prof. dr hab. Jerzy Semków (UWr.) oraz dr Renata Konieczna-Woźniak i mgr Magdalena Barańska (obie UAM). Wygłoszono pięć referatów: dr Sylwia Słowińska (UZ) - „Koncepcja edukacji międzygeneracyjnej w niemieckiej teorii i praktyce”, dr Artur Fabiś (WSA - Bielsko-Biała) - „Wychowanie do śmierci jako element całożyciowego uczenia się”, dr Tomasz Gmerek (UMed-Poznań) - „Edukacja dorosłych w Finlan-

\footnotetext{
${ }^{4}$ Ze sprawozdania H. Solarczyk-Szwec z obrad sekcji I.

5 Ze sprawozdania A. Stopińskiej-Pająk z obrad sekcji II.

${ }^{6}$ Ze sprawozdania J. Semkowa z obrad sekcji III.
} 
dii - teoria i rzeczywistość”, mgr Karolina Nowak-Domagalska (UAM) - „Kształcenie ustawiczne w Norwegii” oraz mgr Hanna Miler-Sławiczek (UAM) - „Kompetencje kluczowe w uczeniu się przez całe życie".

IV sekcję moderowali prof. dr hab. Zdzisław Wołk, dr Joanna Szłapińska (UAM) i dr Anna Wawrzonek (UAM). Problematyka debaty w sekcji ,zderzała nurt teorii i nurt praktyki”7, a pojawiło się w niej sześć wystąpień: „Kształcenie modułowe, pakiety edukacyjne w doskonaleniu zawodowym pracowników” mgr Edyty Kozieł (ITE-PIB, we współpracy z prof. Henrykiem Bednarczykiem), „Teoria Planned Happenstance w kontekście zmieniającego się rynku pracy” mgr Doroty Piskuły (UAM), „Strategie życia codziennego a planowanie kariery zawodowej" mgr. Jerzego Bieleckiego (KOWEZiK - Warszawa), „Konwergentne urządzenia mobilne w całożyciowym uczeniu się” mgr Mariusza Przybyły (UAM), „Dostosowanie kształcenia do potrzeb rynku pracy na podstawie platformy gromadzenia, przetwarzania i udostępniania informacji” mgr Lucyny Białk-Cieślak (PCEUiP - Poznań) i „E-bibliografia ustawicznej edukacji zawodowej” mgr Joanny Tomczyńskiej (ITE-PIB, we współpracy z H. Bednarczykiem).

Ostatnią częścią konferencji była podsumowująca sesja plenarna. Rozpoczął ją akcent muzyczny - mini-koncert w wykonaniu studentów Akademii Muzycznej w Poznaniu. Następnie moderatorzy poszczególnych sekcji przedstawili krótkie sprawozdania i wnioski z obrad sekcyjnych. Kolejnym punktem obrad stała się dyskusja, która objęła zarówno tezy wystąpień plenarnych, jak i wnioski z dyskusji w sekcjach. Zabierali w niej głos m. in. prof. prof. Aleksander, Kargul, Semków, Malewski i Stopińska-Pająk, snując własne refleksje na kanwie przebiegu dwudniowych obrad i podkreślając znaczenie podjętej w ich trakcie tematyki. Próbę podsumowania całości podjęła w słowie końcowym przewodnicząca konferencji - prof. dr hab. Ewa Solarczyk-Ambrozik. Jako że organizatorzy planują wydanie monografii, która zawierać będzie artykuły oparte na referatach zaprezentowanych w czasie obrad, warto rozważyć, czy nie zamieścić w niej także tych interesujących i częstokroć ważkich głosów, które pojawiły się podczas dyskusji w podsumowujących fragmentach gnieźnieńskiej konferencji.

Na zakończenie dodajmy, że w tej bodajże najważniejszej polskiej debacie akademickiej na temat edukacji dorosłych roku 2010 zaznaczyło swoją obecność również środowisko historyków wychowania. Aż dwa referaty plenarne dotyczyły w całości wybranych aspektów z dziejów edukacji dorosłych - prof. Agnieszki Stopińskiej-Pająk oraz wspólny prof. Krzysztofa Jakubiaka i prof. Wiesława Jamrożka. Trzeci, przygotowany przez autora niniejszego omówienia, został zaś zaprezentowany w sekcji ${ }^{8}$. Rozważania historycznooświatowe pojawiły się również w kilku innych referatach oraz w dyskusji (m.in. prof. prof. Tadeusza Aleksandra, Henryka Bednarczyka, Elżbiety Dubas, Dzierżymira Jankowskiego, Mieczysława Malewskiego czy Ewy Solarczyk-Ambrozik). Może to sugerować, że widoczne po 1989 r. a spowodowane chęcią wyraźnego „odkotwiczenia się od złej

\footnotetext{
7 Ze sprawozdania A. Wawrzonek z obrad sekcji IV.

8 Sam autor ma także dodatkowo satysfakcję, że dzięki przypomnieniu postaci ks. Antoniego Ludwiczaka i jego koncepcji uniwersytetu ludowego udało mu się zachęcić przynajmniej część uczestników konferencji do odwiedzenia istniejącej do dziś byłej siedziby pierwszego polskiej placówki tego typu w podgnieźnieńskich Dalkach.
} 
tradycji” - jak niezwykle trafnie określiła to za Z. Baumanem w czasie konferencji Agnieszka Stopińska-Pająk - odwrócenie się rodzimego środowiska andragogicznego od historii wychowania, zaczyna stopniowo słabnąć. Warto być może zatem w środowisku Towarzystwa Historii Edukacji rozważyć, czy nie zacieśnić związków instytucjonalnych ze środowiskiem naukowców prowadzących badania w obrębie współczesnej polskiej edukacji dorosłych - np. przez podjęcie wspólnych przedsięwzięć naukowych z odpowiednikiem THE w gremiach andragogicznych, a więc Akademickim Towarzystwem Andragogicznym. Wspólne prace THE i ATA nad „powtórnym zakotwiczeniem” polskiej andragogiki - tym razem już w Baumanowskiej „dobrej tradycji”" mogłyby zapewne przynieść interesujące poznawczo i ważne dla obu środowisk naukowych efekty.

Tomasz Maliszewski

\section{Seminarium naukowe nt. „Warsztat badawczy współczesnego historyka wychowania" (Obrzycko, 28-29 czerwiec 2010)}

W dniach 28-29 czerwca 2010 r. w Domu Pracy Twórczej i Wypoczynku w Obrzycku, odbyło się seminarium zorganizowane przez Zakład Historii Wychowania Uniwersytetu im. Adama Mickiewicza w Poznaniu. Jego tematem przewodnim był „Warsztat badawczy współczesnego historyka wychowania”, co spotkało się ze znacznym zainteresowaniem zgromadzonych osób. Byli to nie tylko pracownicy i doktoranci UAM, ale także osoby od wielu lat współpracujące naukowo z Zakładem Historii Wychowania (przede wszystkim z Akademii Pomorskiej w Słupsku, Uniwersytetu Medycznego w Poznaniu, Uniwersytetu Przyrodniczego w Poznaniu, ŁWSH w Żarach, Muzeum Warmii i Mazur w Olsztynie).

Uczestnicy seminarium zostali uroczyście powitani przez kierownika ZHW prof. dra hab. Wiesława Jamrożka oraz prof. dr hab. Dorotę Żołądź-Strzelczyk. W związku z tym, że część uczestników seminarium nie miała okazji wcześniej się poznać, postanowiono, że każdy z obecnych dokona autoprezentacji z uwzględnieniem swoich zainteresowań badawczych.

Kolejnym punktem obrad był wykład inauguracyjny, wygłoszony przez prof. Romana Tomaszewskiego, nt. „Przypis jako zdobnik mitu - uwagi o metodologii badań regionalnych historii wychowania”. Prof. R. Tomaszewski (z Akademii Pomorskiej w Słupsku) przedstawił w nim m.in. zarys rozwoju badań regionalnych, podkreślając, że przez długi czas gromadzono dzięki nim jedynie fakty, co zdaniem tego badacza dzisiaj zasługuje na

${ }_{9}$ Z wystąpienia prof. Agnieszki Stopińskiej-Pająk, Gniezno, 21-06-2010. 